\title{
Kentsel Adaletin Temsil Edil(e)memesi Ekseninde Ekümenopolis (Ucu Olmayan Şehir) Filminin Sosyolojik Okuması
}

DOI: $10.26466 /$ opus.688339

*

\section{Yonca Altındal *}

* Dr. Öğr. Üyesi, Balıkesir Üni. Fen-Edebiyat Fak. Sosyoloji Böl, Uygulamalı Sosyoloji ABD, Balıkesir/Türkiye

E-Posta: yoncaaltindal@balikesir.edu.tr

ORCID: $\quad \underline{0000-0002-1240-127 X}$

\begin{abstract}
Öz
Kentleşme, modernleşme ve kapitalistleşme olguları arasında karşıllklı bağlamsallık söz konusudur. Kentin toplumsallığında kurulan ilişki dinamikliği bu anlamda değer kazanmaktadır. Ancak kurulan bu dinamizmin kentsel yaşamda bütünüyle devingenlik să̆ladığg anlamına gelmemektedir. Oysa kent, kendi toplumsal ve kültürel dokusuyla özgünlük barındırmalıdır. Sımıfsal farklılıkların çatışmalara sebep olmadığı kentlerin var olabilmesi bu anlamda önem taşımaktadır. Buna karşın eşitsiz mekânsal ayrışmalar, kamusallı̆̆ın tasarlanışı ile kent politikalarını ve kentleşmedeki egemen yapının temel nüvelerini derinden etkilemektedir Bu çalışma Ekünemopolis (Ucu Olmayan Şehir) belgesel filminin sinıflar arası kutuplaşmanın mekânsal ayrımlaşmaya sebebiyet veren tezahürünü sosyolojik perspektifle sorgulamayı hedeflemektedir. Bunu gerçekleştirebilmek amacıyla öncelikle ilgili belgeselde kent, kentleşme, kentsel dinamizm, kentsel adalet, yoksulluğun görünümü, kentsel dönüşüm, kentin yapılandırıcıları, politikacılar, yerinden edinmeyi deneyimleyenler, bu olayı tartışan mimarlar, akademisyenler ve şehir plancılarının görüşleri üzerinden değerlendirilecektir. Çalı̧̧mada ayrıca belgeselde sunulanın arda planın ve alt metnini anlayabilmek için filmden belli kesitler sunulmak ve sosyolojik perspektif temel alınmaksuretiyle kentsel adaletin nasıl oluşturul(a)madı̆̆ı eleştirel bakış açısı ile analiz edilecektir.
\end{abstract}

Anahtar Kelimeler: kent, kent hakkı, kentsel eşitsizlik, Ekümenopolis (Ucu Olmayan Şehir) 


\title{
On the Axis of theRepresentation of Urban Justice Sociological Reading of Ecumenopolis (City Without End)
}

\begin{abstract}
There is a reciprocal contextuality between the phenomena of urbanization, modernization and capitalization. The relationship Dynamics established in the sociality of the city gain value in this sense. However, this does not mean that the dynamism established provides the mobility in urban life. However, the city should possess originality with its social and cultural texture. The existence of cities where class differences do not cause conflicts is important in this sense. Despite that unequal spatial discrimination deeply affect the design of publicity and urban policies and the cores of the dominant structure in urbanization. This study aims to question the manifestation of the polarization of the classics of Ecumenopolis (City Without End) which causes spatial segregation from a sociological perspective. In order to realize this, firstly, the documentary will be evaluated from the point of view of thecity, urbanization, urban dynamism, urban justice, the appearance of poverty, urban transformation, thecity's constructors, politicians, those who experience displacement, architects, academicians and cityplanners who discuss this event. In this study, in order tounder stand the succession plan and sub-text of the documentary, certain sections of the film will be presented and how the urban justice is not formed (a) will be analyzed with a critical point of view based on sociological perspective.
\end{abstract}

Keywords: urban, urban rights, capital, Ecumenopolis 


\section{Giriş}

Kentleşme, modernleşme ve kapitalistleşme arasındaki ilişkiselliğin dinamik doğası pek çok değişimi de beraberinde getirmiştir. Oluşagelen devinim, toplumsallığın farklı bağlamlarında kendisini göstermiştir. Kentin konumu, ekonomik, toplumsal ve kültürel yapılanması nüfusun temel belirleyici olma özelliğinin dışında düşünmeyi de dâhil etmeyi gerektirir. Öyle ki kentin gelişmişlik göstergesi de tek başına nüfusun yoğunluğu üzerinden çok ekonomisinin nasıl şekillendiği, sınıflar arasındaki gelirin ne şekilde pay edildiği, hangi sektörlerin ön planda tutulduğu noktasına taşımaktadır. Bunun yanı sıra sosyal politikaların kentteki içerimleri, kentin sadece yap1lardan oluşan görünümünün dışında eğitim, sağlık, çevre, sosyal konumlandırılışına dair pek çok sosyolojik olgunun da tartısılmasını beraberinde getirmektedir. Dolayısıyla artı günümüzde kentin var olabilmesi nüfusun kentte nasıl dağıldığı ve kentte sınıflar arasında konutların ve yaşam alanlarının nasıl ayrımlaştığı noktasına dairdir. Bu dağılım kentsel adaletin temsil edilip edilmediğine dair önemli izlekleri de gün ışığına çıkarmaktadır. Altındal'ın da belirttiği üzere "bugün klasik anlamını kaybeden kentleşme, farklı mekanlardan, farklı etnik yapılar ve kültürlerden, yine farklı beklentilerle gelen insanların, bir coğrafi mekanda yoğun olarak toplanmasıyla ortaya çıkan bir olgu olmanın ötesinde, sadece farklılıkların yan yana mekanlara yerleşerek oluşturdukları nüfusun yığılma alanları özelliğini taşır olmuştur" (Altındal, 2010, s.72). Bu yığılma alanlarının yapısı gelişmiş ve azgelişmiş ülkeler arasında farklılık göstermektedir.

Ülkelerin gelişmişlik düzeylerine bakıldığında bu farklılığın özellikle azgelişmiş ülkelerdeki kentleşme sürecine ve sanayileşme ile ilişkisinde belirginleştiği görülmektedir. Davis'e göre, üçüncü dünya ülkelerindeki kentleşme süreci, ücretlerin düşmesine, fiyatların yükselmesine ve artan işsizlik oranlarına rağmen, 1980'ler ve 1990'larda da devam etmiştir. Azgelişmiş ülkelerde, Uluslararası Para Fonu (IMF), Dünya Ticaret Örgütü gibi küresel örgütler ve gelişmiş ülkeler tarafından desteklenen, tarımda daralma ve köylülükten çıkarma politikaları sonucunda, kırsal alandaki işsizlik hızla artmıştır. Kırsal alanda işsiz kalan tarım işçileri için şehirlerde iş bulmak da artık çok güç hale gelmekle birlikte gecekondu bölgelerine göç hızlanarak devam etmiştir (Davis, 2007, s.20-21). Lloyd (1979) da azgelişmiş ülkelerde kentlere göçlerin artış göstermesi sonucunda, kalabalık şehirlerdeki büyük 
çoğunluğun yıkıntı bölgelerinde yaşadığını, özellikle 1960'larda Manila ve Cakarta'da nüfusun dörtte birinin, Meksika City'de üçte birinin, Ankara ve Lima'da ise yarısının bu bölgelerde yoğunlaştı̆̆ını ifade etmiştir.

Az gelişmiş ülkeler, kapitalizmin hegemonik merkezleri tarafından etkilenmekte ve ilerleme sürecinde gerçekleştirebildikleri düşük artışlar nedeniyle, kalkınma düzeyinde gelişmiş ülkelerle aralarında var olan ekonomik uçurumun kapanması bir yana, gittikçe büyümesi sonucu her yıl biraz daha geride kalmaktadırlar. Türkiye'ye orta ve üst gelir grup konut bölgeleri ile alt sınıfsal yığılma açısından bakıldığında, kentlerin farklılaştığı görülmektedir. Sınıfsal bağlam, kentlerin yerleşim alanlarındaki mekânsal ayrımlaşmayı da beraberinde getirmekte ve böylelikle eşitsiz dağılım kendisini açıkça hissettirmektedir (Altındal, 2017, s.401). Mekânsal ayrımlaşmanın alt metninde Urry'nin kavramsallaştırmasıyla kirlenme olgusunun yattı̆̆ını söylemek mümkündür. Etiketlenen yani damgalanan göç eden insanların Altındal'ın kavramsallaştırmasıyla (2010) yeni kentlilerin kentin merkezinden çeperine, hatta çeperin de dışına itilmesi sınıfsal ayrımlaşmanın mekânsal düzlemdeki göstergesidir. Günümüzde Şengül'ün dikkat çektiği gibi “geleneksel kent merkezlerinin yerini alan alışveriş merkezleri kendi çekim alanlarını oluşturmaktadır. Tekli merkezlerin yerini çoklu merkezler aldığı için her bölgede kendi çekim alanını oluştururken, bir yandan da sosyal tabakalaşmaya neden olmaktadır. Ancak bu durum demokratikleşmekten öte sınıfsal dışlamalara yol açmaktadır" (Şengül, 2016). Yine bu eşitsiz yapılanmalar mekânsal ayrımlaşmaları da aşarak aynı zamanda sosyal dışlanma, yoksulluk, işsizlik gibi pek çok toplumsal ve ekonomik sorunu da beraberinde getirmektedir. İşsizliğin en temel sebeplerden biri de 1980'li yıllarla birlikte neo-liberal politikaların etki alanın genişlemeye başlamasıdır. Özellikle iş imkânını yaratan yegâne yerlerin kentler olduğu iddiasıyla burada yaşayan işsizler için 'cazibe merkezleri' olduğunu varsayan söylemler dillendirilmeye başlamıştır. Ancak göçlerle birlikte oluşan toplumsal ve mekânsal sorunlar da söz konusu olmuştur. Bunun en temel sebebi "neoliberal politikalar ile sermaye ve devlet arasındaki ilişkinin değişime uğramasıdır. Devletin mekâna müdahale aracı olan kent planlaması anlayışındaki değişimler toplumun bütününü etkilemiştir. Planlardaki parçacı yaklaşım ve kaynak dağıtımında dengenin sağlanamaması, mekânda ayrışmayı da beraberinde getirmiştir. Bu nedenle büyük kentsel projeler, kentsel dönüşüm projeleri ve planlar neo-liberal politikaların ayrımcı yapısı gözetile- 
rek parçacı bir yaklaşımla ele alınmıştır" (Uyanıker Kırbaç, 2017, s.54). Kurtuluş da benzer görüşü savunarak "gerek eski metropoliten alanlarda, gerekse yeni gelişmekte olan metropollerdeki hizmet ve sanayi sektörü tarafından, özellikle Güneydoğu Anadolu Bölgesinden zorunlu göç ve ekonomik nedenlerle göçmek zorunda kalan kesimin ucuz işgücü olarak emilmesinin yanında, aynı zamanda kentsel arazinin de değerlenmesi nedeniyle bu yeni ve yoksul göçmenler için barınmanın dramatik bir sorun olarak ortaya çıktığını, bunun doğal olarak kentlerin belli alanlarına yoksulluğun yığılması ile yeni yoksulluk mekânlarının oluşmasına neden olduğunu belirtmiştir" (Kurtuluş, 2010, s.216).

Barınma hakkının yeterli düzeyde görülmediği yerlerde eğitim ve sağlık hizmetlerinin alınmasından bahsedilmesi mümkün gözükmemektedir. Çocuklara yaratıc eğitimi veren okullar ya kentin merkezindeki devlet okullarında ya da firsat eşitsizliğini arttıran özel okullarda kampüs yapılanması içerisinde kentin dışında toplanmıştır. Gecekondu bölgelerinde verilen eğitimlerin yeterliliği açısından bakıldığında ise pek çok sorun bulunduğunu söylemek mümkündür. Sınıfsal bağlamda bakıldığında gerek erişimdeki sıkıntılar gerekse eğitimin sunduğu olanaklar açısından ciddi anlamda eşitsizlikler söz konusudur. Ayrıca özellikle Türkiye özelinde şehir hastaneleri ve tıp fakültelerinin kentin dışında yapılandırılması alt sınıfların sağlık hizmetlerinden yararlanma olanaklarını azalttı̆̆ı, böylelikle bu alanlara ulaşımda da eşitsizliğin yaşanmasına yol açtığı ifade edilebilir. Vatandaştan müşteriye doğru olan neo-liberal dönüşümde eğitim ve sağlık alanlarında görülenler kentsel eşitsizliğin en temel göstergeleridir. Yoksulluk mekânlarından olan gecekonduların hızla sayısının çoğalması, akabinde burada yaşanan hayatların da özellikle ekonomik boyuttan doğrudan etkilenmesine yol açmaktadır. Dolayısıyla Erder'in de özellikle bahsetmiş olduğu gibi kentlerde, kırsal göçmenlerin maddi imkânsızlıkları sonucunda ortaya çıkan gecekondu alanlarının gelişimi ve dönüşümünde en önemli belirleyici unsur ise yoksulluğun artmasıdır. Ekonomik ve toplumsal değişimler nedeniyle yoksulluk yalnızca gelir azlığı ile meydana gelmemektedir. Küresel çaptaki müdahalelerle azgelişmiş ülkelerin çöken ekonomileri, buna bağlı olarak farklılaşan toplumsal yapı içinde yeniden şekillenen sınıfsal yapı içinde oluşan uçurumlar, kentsel sosyal hizmetlerin ve sosyal devletin koruyuculuğunun ortadan kalkması ile kentlerdeki yoksullar daha zor koşullar altında yaşamaya mecbur bırakılmıştır (Erder, 2001, s.32-36). 
Gecekondu alanlarında yaşanan yoksulluk, gelir yoksulluğundan farklı olarak kapasite yoksunluğu ve sosyal dışlanmışlığı da içinde barındıran yoksulluk olarak yaşanır. Temel ihtiyaçlar, artık yalnızca yiyecek, su, giyim, barınak değil, bunlarla birlikte eğitim, sağlık, politik süreçlere ve kamusal yaşama katılım, güvenlik ve saygınlık kriterlerini de kapsamaktadır. Bu kapsam açıklanırken önemli bir noktanın da altı çizilmiştir. Tüm dünyada toplumsal yapının, tüketim doğrultusunda şekillenmesi ile değişen yaşam biçimlerine bağlı olarak değişmesi ile birlikte her ülke ve kültürün kendi değerleri ve normlarına göre farklılık göstermesi (Hulme, Shepherd, Moore, 2001) ise de, asıl olarak belirtilmesi gereken temel nokta ise Goffmann'c1 kavramsallaştırma üzerinden değerlendirildiğinde etiketlenen yani damgalanan kentin çeperlerinde yani periferisinde yaşayan insanların gerçek anlamda 'ne kadar iyi yaşam koşulları sürebildikleri' sorununa ilişkindir. Sanayi, ucuz işgücünü sömürmek amacıyla kentin dışına doğru taşmakta ve kentlerin yapısı hizmet sektöründe güvencesiz iş kollarında yaşayan yığınların tüketim mekânları haline gelmektedir. İzole yaşamların mekânsal düzlemdeki yansımaları da bu hizmet işçilerinin yaşam mekânlarının değiştirilmesiyle bambaşka bir hale bürünmesine yol açmaktadır. Yeni yaşam alanları yoksullar açısından bakıldığında, ekonomik alandaki istihdam alanındaki görünümü ve bunun devamında toplumsal alanlarda adeta keskin çizilmiş sınırlara hapsolmuş öykülerden ibaret olduğunu ifade etmek mümkündür. Enformel sektörün güvencesizliği bu ekonomik alandan dışlanma yanında gündelik hayatın içerisinde de var olamamaya doğru uzanabilecek sonu mutsuz bir hikâyeyi okumaya ve yaşamaya itmektedir.

\section{Türkiye'de Kentleşme ve Göç Öyküsü}

Kentsel alanın mevcut varlığı, bu alanın sadece fiziksel bir yer mi, yoksa aksine kurulan ilişki ağlarıyla şekillenen sosyal bir mekân olarak mı var olduğunu göstermektedir. Sosyolojik bir okumayla konuya yaklaşıldığında; kent ve kentleşme dinamiği akışkanlığı içerisinde barındırırken, kentsel adalet anlayışının nasıl olduğuna dair bilgi de vermektedir. Kentsel adalet, sınıflar arasında yaşanan mekânsal farklılığı ve gündelik yaşamın sosyolojisini sunarken, bir yandan da varsıl ile yoksul kesim arasındaki kentin nasıl pay edildiği sorunu da bulunmaktadır. Bu bağlamda kentleşme öyküsü 
kentsel adalet anlayışının; yoksulluğun ve yoksunluğun nerede ve ne şekilde yaşandığına dair mevcut görünümleri irdelemeyi de gerekli kılmaktadır.

Türkiye'nin kentleşme serüvenini anlayabilmek için Türkiye'nin kitlesel anlamda göç olgusu ile tanışmasına bakmak önem taşımaktadır. 1940'lı yılların sonlarında kentleşmenin seyri, Marshall yardımları nedeniyle tarımda makineleşmeye geçiş süreci ile başlamış, beraberinde yoğun iç göç dalgası sonrasındaki kent politikalarının liberal ve neo-liberal piyasacı yapısı üzerine şekillenmiş̧ir. Bu yıllarda İstanbul ilk olarak içgöçle tanışmışsa da, bu göçün geçici bir olgu olduğu var sayılarak, göçmenlerin bir süre sonra geldikleri yerlere geri dönecekleri düşünülmüştür. Bu nedenle ilk gecekondulaşmalar, fazlaca dikkat çekmemiş, sonraki yıllarda büyük kentsel sorunlara yol açabileceği endişesi gündeme gelmemiştir (Işık, Pınarcıoğlu, 2001). Oysa sosyolojik anlamda göçün, sadece kırdan veya küçük kentlerden büyük kentlere aktarılan nüfusun yer değiştirilmesi ile sınırlandırılmaması, bunun yanında, ekonomik, toplumsal, kültürel ve politik düzeydeki değişim ve dönüşümleri de içinde barındıran bir olgu olarak ele alınması gerekmektedir.

Gecekondulaşmanın insanları mekânsal ayrımlaşmalarda kümelenmelerine itmesi Tekeli'nin de belirttiği üzere Türkiye'de emek hareketliliğinin kentleşme sürecine fazlasıyla etkide bulunmasına yol açmıştır. Öyle ki modernleşmenin ilk yıllarından bu yana sürekli devam eden içgöç, kentleşme sürecinin vazgeçilmez bir parçası olmuştur (Tekeli, 2007, s.445). Azgelişmiş bir ülke konumunda olan Türkiye özelinde göç olgusu da bu bağlamda, terk edilen ve özellikle de göç edilen mekânlarda meydana getirdiği değişiklikler nedeniyle toplumsal dönüşümün en önemli göstergelerinden birini oluşturmaktadır.

Keleş'e göre gecekondu "bayındırlık ve yapı kurallarına aykırı olarak, gerçek ya da tüzel, kamusal ya da özel kişilerin toprakları üzerine, toprak iyesinin istenç ve bilgisi dışında onarımsız olarak yapılan, barınma gereksinimleri devletçe ve kent yönetimlerince karşılanamayan yoksul ya da dar gelirli ailelerin yaşadığı barınak türüdür" (Keleş, 1993, s.382). Bu doğrultuda kentleşmenin, köylülüğün çözülmesiyle köy ve kent arasında karşıllklı olarak diyalektik bir süreç biçiminde başladığını ve halen devam ettiğini söyleyebilmek mümkündür. Yine buna bağlı olarak, özellikle son elli yıldır mekan bağlamında Türkiye'de formel kent düzenlemesi, enformel gecekondulular ile karşılıklı olarak gelişme göstermiş ve kentsel mekanın diyalektik 
inşa sürecini oturtmuştur. Köylerden kentlere başlayan göç nedeniyle özellikle de büyük şehirlerde nüfusun ani artışı sonucu ortaya çıan ek konut ihtiyacl, konut ve arsa fiyatlarının yükselmesine yol açmıştır (Altındal, 2010,s.73).

Konuya bu bakımdan yaklaşıldığında, kentin taşıyabileceğinden daha fazla nüfus barındırması nedeniyle mekân boyutuna yansıyan sorunların başında gecekondu sorununun geldiği söylenmelidir. Gecekondulaşma Türkiye'de kırsal alanlardan büyük kentlere doğru emek hareketliliğinin bir sonucu olarak çıan hem mekânsal hem de toplumsal anlamda oluşum ve dönüşüm sürecini belirtmek için kullanılmaktadır. Göç eden insanlar barınma gereksinimlerini karşılamak için kendi konutlarını özellikle kentlere yakın kamu arazilerine gecekondu inşa ederek gidermişlerdir. Ancak göçlerin yoğunluğundan dolayı zaman içerisinde gecekondu alanları genişleyerek, bu alanlarda enformel ilişki ağları kurulmuş ve yeni gecekondular yapılmıştır. İşin ilginç olan noktası, mutlak suretle devlet eliyle yıkılması gerekli görülen gecekondular, kimi zaman özellikle de genel seçimler öncesi verilen sözler doğrultusunda devlet eliyle uygulanan popülist politikalar etrafında göçmenlere tapu verilerek yasallaştırılmıştır. Bu bağlamda, gecekondulaşma olgusunun Türkiye'de oldukça hızlı bir şekilde gelişim göstermiş olduğunu söylemek mümkündür.

$\mathrm{Bu}$ doğrultuda gecekondulaşma olgusunun, ilk gecekondulaşmanın başladığı yıllarda sanıldığının aksine geçici bir süreç olmayıp, kır ile kent arasında belirli bir dönem içerisinde ortaya çlkan geçiş döneminin ürünü ve kentleşme sürecinin yapısal bir dinamiği olarak ele alınması gereken bir olgu olduğu anlaşılmaktadır. Türkiye'de gecekondu olgusu, esas olarak bütünüyle kıra da, kente de ait olmayan, geçiş dönemindeki değişimin ürünü olarak dengeleyici bir rolü üstlenen 'tampon mekanizma' olarak öne çıkan bir olgu özelliği taşıması nedeniyle bu yönüyle de sosyolojik değerlendirme konusudur. Bu bağlamda, "tampon mekanizmalar değişmenin bunalımsız olmasını sağlayan, çözülmenin önüne geçen ve her iki sosyal yapıya da ait olmayan yeni beliren kurumlar, ilişkiler, değerler, fonksiyonlar" (Kıray, 2000, s.20) olarak tanımlanmaktadır. Dolayısıyla gecekondulaşma bütünüyle köye de, kente de ait olmayan, kentte yer almakla birlikte kentin ürünü olmayan özellikleri nedeniyle değişim ve dönüşümlere olanak tanıyan toplumsal bir olgudur. Bu özelliği ile gecekondulaşmayı, Türkiye'de kentin ve kentleşmenin doğal bir parçası olarak değerlendirmek mümkün- 
dür. Gecekondular bu yönüyle üretim ilişkilerinin yaratmış olduğu çelişkilerin mekâna yansıması olarak tanımlanabilir. Ancak Tekeli'nin de belirttiği üzere gecekondu bölgeleri 'modernitenin meşruiyet kalıpları' dışında (Tekeli, 2007, s.466) görülen ve uzun yıllar boyunca 'dışlanmışlık' yaftası ile eş tutularak yaşanan bir toplumsal olgu özelliği taşımıştır. Kentleşmede önemli bir dinamizm sağlayan, ancak hem devlet hem de piyasa tarafindan, bir yandan olumsuz olarak nitelendirilen gecekondulaşma sürecine, öte yandan görmezden gelinen ikircikli bir tutum takınıldığı gözlenmektedir. Işık ve Pınarcioğlu tarafından da "gecekondu hem formel konut piyasasının, hem de devletin dışladığı kesimlere yönelik piyasa dışı bir çözüm olarak ortaya çıkmıştır. Gecekondunun en başından itibaren çok net bir sınıfsal içeriği vardır. Gecekondunun, kente yeni gelen, kentte tutunmaya çalışan ve devlet ile piyasanın unuttuğu, yok saydığı kesimlerin konutu olduğu" (Işık, Pınarcioğlu, 2001, s.112) şeklinde ifade etmeleri bu anlamda dışlanmışlı̆̆ ortaya koymada önemlidir.

İlk kuşak gecekonduların temel özelliği, göçmenlerin kentin çevresinde yer alan hazine arazileri üzerinde esas olarak kendi emekleri ile bir gecede oluşturmalarıyla gerçekleştirilmiş olmasıdır. Kentleşmenin ilk dönemlerinde ortaya çıkan gecekondulaşmanın bir başka özelliği de değişim değeri olmasından çok, kullanım değeri için üretilmesidir. Işık ve Pınarcıŏlu'na göre "bu ilk dönem gecekonduların genel yapısına bakıldığında, gerek gelir düzeyi, gerekse kentte yaşadığı deneyimleri dalgalanmalar gösterebilen bir kesimin konutu olarak ifade etmek mümkün gözükmektedir" (Işık, Pınarcloğlu, 2001, s.112). Ancak zamanla gecekondu bölgeleri hukuki meşruiyet kazanmıştır. Popülist seçim propagandaları sırasında, gecekondu sahiplerine tapu verilmesi gündeme gelmiş ve 'gecekondu afları' yaşanmıştır. Böylece gecekondular devlet eliyle illegallikten çıarılarak legal bir statüye kavuşurken, izlenilen bu politika, gecekondulaşma sorununu çözmemesi bir yana, gecekondulaşma hızını arttıran önemli bir etken olmuştur (Keleş, 2008). Çarpık kentleşmenin nedenlerinden biri olarak ortaya çıktığı belirtilen ve kırsal alandan kente yapılan göç sonucu oluşan gecekondular, kent çevresini sarmal olarak kuşatan özellikleri ile önceleri sıra dışı bir kent mekân tipi olarak yer almışken, uygulanan popülist politikalar sonrasında gerçekleştirilen imar afları ile bir kent gerçeği olarak hukuksallık kazanmışlardır. Devletin gecekonduya ilişkin ilk resmi tepkisi olan 1966 tarihli 775 sayılı Gecekondu Kanunu ile gecekondu alanlarına yönelik yasallaştırma 
işlemlerine gidilirken, bu alanların imara açılması sırasında, devreye 'yapsatçlar'ın girmesi ve 'gecekondulardan temizleme' işleminin piyasa mekanizmasına verilmesi ilginç bir tablo olarak literatürde yerini almıştır (Işık, Pınarcioğlu, 2001).

Gecekondu kavramı da olağan süreçte Türkiye özelinde tarihsel ve politik arka planda evrime uğramıştır. Gecekondunun tarihsel ve toplumsal bağlamdaki dönüşümüne bakıldığında, 1950'de Demokrat Partinin genelde köylerde ve kentlerde de özellikle gecekondu kesiminin oyların alarak iktidara gelmesi, gecekondunun evrim sürecinde birinci kırılma noktasını oluşturmuştur. 1940'lı yıllarda gecekondu bölgelerinde dağınık bir barakalaşma ve yoksulluk hâkimken, 1950-1960 yıllarını, 'mahalleleşme', ve kente 'yerleşme' dönemi olarak değerlendirmek mümkündür. 1960'ların başından itibaren 'ekonomik mekânda ithal ikame' modelinin yaygınlaşması, gecekondu nüfusu için bir diğer kırılma noktası olarak kabul edilebilir. Bir dönemde iç pazardaki arz ve taleplerin devamı, özellikle yurtdışından gelen döviz desteği ve kırsal kesimin sübvansiyonu yanında, gecekondu nüfusunun kentle bütünleşebilme amacıyla yeni 'enformel' dağıtım kanalları kurularak, kentli tipi tüketime yöneltilmesi ile sağlanabilmiştir. Tüm bunların dışında, ekonomik sektörlere ucuz işçi getirilmesi yanında, kırdan transfer edilen sınırlı sermaye, iç borçlanmalar ve ilişki ağları ile yeni kentlilerin yeni mekândaki yerleşmesini güçlendirip yenilemiştir (Şenyapılı, 1998).

Yukarıda açıklanan tüm açıklamalar dikkate alındığında, "kentkentleşme-kentlileşme-göç ve gecekondu" olgularının sosyolojik analizinin yapılmasının elzem olduğu görülmektedir. Kentin devinimi ve beraberinde görülen mekânsal ayrımlaşma son yıllarda da kendisini açıkça göstermektedir. Marshall'ın da belirttiği üzere günümüz kentlerinin belirgin özelliklerinden birisi olarak kabul edilen ayrımlaşma belirli bir birey ve toplumsal grupların, çok az iletişim kurarak ya da hiçbir etkileşim olmadan birbirinden ayrı kalmasıyla sonuçlanan toplumsal süreç olarak tanımlanmaktadır (2003).

\section{Neo-Liberal Rüzgâr ve Bitmeyen Esintisinde Kent-Mekân-Sınıf-İktidar İlişkisi}

2000'li yılların özel sermaye ile yakın flörtü dünyadaki genel konjonktürüyle benzer toplumsal süreçlerden ve dinamiklerden geçen Türkiye örneğin- 
deki neo-liberal politikaların egemen olmasıyla eş tutulduğunu söylemek yanlış olmayacaktır. Çünkü 1980'li ve sonrasındaki yıllarda, küreselleşmenin, neo-liberal ekonomi politikaları uygulamalarının tüm boyutlarıla dünyadaki üretim ve emek örgütlenmelerine, düzenleme mekanizmalarına damgasını vurduğu, dünyada coğrafi-mekânsal ölçeklerin ve hiyerarşilerin yeniden yapılandığı, kentlerin bu yeni işbölümü ve ölçekler çerçevesinde şekillendiğini söylemek mümkündür (Brenner, 2000; Warner ve Gerbasi, 2004). Bu yeni dönem ile birlikte, emeğin yönünü sınıfsal eşitlik bağlamından uzaklaştırılarak, Keynesyen refah devletinin uygulamalarından tamamıyla farklılaştığı yepyeni bir tarihsel dönemeçte yaşanmasına geçilmiştir. Clarke'ın bahsetmiş olduğu gibi bu dönem "ikinci dünya savaşı ile ekonomiye egemen olan ithal ikameci sanayi modeli ve Keynesçi politikaların 1970'lerin sonlarına doğru çöküşe geçmesi ile Keynesyen refah devleti krizine ideolojik bir tepki olarak ortaya çıkmıştır" (Clarke, 2005, s.58).

Refah devletinin sona ermesi ile kesilen kamusal hizmetler ve yatırımlar bir yandan geleneksel işçi ve memur kesiminde ciddi sosyal güvence kayıplarına neden olurken, diğer yönden sanayisizleşme ve enformelleşmede de geniş ölçekli kayıplara uğramaktadır. Aynı zamanda savaş sonrası sosyal refah politikaları ile mekânda yerleşmiş sınıfların yarattıkları sosyomekânsal ölçekli bir yerinden edilme ve mobilizasyonda gerçekleşmektedir. Bir yandan kentin geleneksel sınıflarının yaşadıkları mekanlardaki dönüşümler, diğer yandan da sermaye birikiminin hızının yükselmesi belli kentsel bölgelerin aldıkları düzensiz ve enformel göçler, kentlerde ciddi bir kentsel yoksulluk sürecini de birlikte etkilemiştir (Davis, 2007). Altındal'ın da bu doğrultuda dikkat çektiği üzere emek piyasası, 1960'ların öncesi ve sonrası olmak üzere iki büyük değişim göstermiştir. Sosyal refah devletinin bireyi vatandaşlığa taşıyan anlayışı, 1960'ların sonu özellikle 1970'lerdeki toplumsal dönüşümler nedeniyle tamamıyla farklı bir kulvarda yerini almaya başlamıştır. 1970'ler petrol krizinin patlak verdiği ve kapitalizmin geçirdiği bu krizin piyasada özelleştirmeye yönelerek aşılmaya çalışıldığı bir dönemi ifade etmektedir. Vatandaşlıktan müşteriliğe dönüşüldüğü, emeğin parçalandığı, değersizleştiği, hafifsendiği, emekçilerin kadrolu ve garantili iş bulabilme olanaklarının azaldığı, hatta yok olduğu, üretimin esnekleştiği, kayıt dışı ekonomi olarak tanımlanan enformel işgücü piyasasının artış gösterdiği, insanların günü kotaran, yarının ne olduğu belirsiz iş kollarında istihdam edildiği yeni bir dönem olarak ortaya çıan postfor- 
dizm, eşitliğin, sosyal hakkın, güvencenin, sendikalı olmanın, sağlıklı çalışma koşullarının imkanlarını ortadan kaldırmıştır (Altındal, 2017). Dolayısıyla emek piyasalarının esnekleştirilmesi, özelleştirme, sermaye odaklı ekonomi politikaları, girişimcilik gibi neo-liberal politikalar, büyük ölçekli kentsel projelere ve mekânı pazar haline getiren rekabet ortamına zemin hazırlamıştır (Moulaert, Swyngedouw ve Rodriguez, 2001, ss.100-101). Bu bağlamda emek değerini yitirmiş bir konumsuzlukla eş değer tutulmaktadır. 1980'lerde özellikle küreselleşme sürecinde uygulanan yapısal uyum programları ve ihracata dayalı büyüme stratejileri de bu serbest piyasacı anlayış, politika ve uygulamaların alanını genişletmiştir. Kurtuluş'un da özellikle belirttiği gibi “Türkiye'nin kentleşme deneyiminde belki de en radikal evre, 1980'li yıllardan itibaren başlayan, 1990'larda açıkça izlenen ve 2000'lerde hâkim kentleşme modeli olarak yerleşen neo-liberal kentsel yeniden yapılanma sürecidir. Devlet, bu yeni birikim sürecinde kentsel mekânı, daha önceki yıllarda olduğu gibi dolaylı yollardan değil, doğrudan düzenlemeler ve teşviklerle büyük sermayenin birikim alanı haline getirmektedir. Bu gelişmeler çerçevesinde sadece metropolitan alanlar değil, kıyısal yerleşmeler de büyük ölçekli sermaye yatırımları ile radikal dönüşümler geçirmeye başlamıştır" (Kurtuluş, 2010, s.214).

Yine Ecevit'in de ifade ettiği üzere, yeni liberalizm ve beraberinde uygulamaya konulan yapısal uyum politikaları gündeme gelmiş, bu politikalar krizden çıkmak isteyen ülkeler tarafından yoğun olarak uygulanmış ve sonuçları da 1980'li yılların ikinci yarısından itibaren ortaya çıkmıştır. Gelişmiş ülkeler uyguladıkları bu politikalar sonucu, istikrarlı büyümelerinin yanında enflasyon oranını düşürüp, işsizlik oranını azaltmayı başarırken; yapısal uyum politikalarını uygulayan ülkeler ise dış borç ve faizler nedeniyle kaynaklarını gelişmiş ülkelere transfer etmek zorunda kalmaları nedeniyle büyüme için gerekli yatırımları yapamamışlardır. Büyümenin yetersizliği ise üretimin azalması, yüksek oranda işsizlik, gelir azalması gibi sonuçların doğmasına sebep olmuştur (Ecevit, 1998, s.31-47).

Azgelişmiş ülkeler açısından periferi olarak ekonomik anlamda ortaya çıkan yoksunlaştırma, daha önce de ayrıntılı bir şekilde bahsedildiği gibi toplumsal ve politik anlamlarda da dışlanılmaya ve merkez ülkeler tarafından bağımlı hale getirilmeye çalışılmaktadır. Böylelikle istihdam sorunu, gelir adaletsizliği, sınıfsal uçurumun derinleşmesi, pastadan en büyük payın \%5'lik kısma ait olup geri kalan \%95'lik kısmı üzerinde tahakküm ku- 
rulması, özellikle ekonomisi dışa bağımlı ülkelerin hayatta kalabilme mücadelelerini çok daha zorlu bir yöne itmektedir. 1980'lerle başlayan güvencesiz, sigortasız iş kollarında yer alış, içgöçte 1940'l1 yıllarla birlikte başlayan ucuz emeğin daha da artarak derinleşmesine yol açmıştır.

\section{Ekümenopolis (Ucu Olmayan Şehir) Filmini Sosyolojik Perspektifle Okumak}

Türkiye özelinde de mekânsal ayrımlaşmanın görüngülerinden ve bunun yaşamsal deneyimlerinden birisi de 2011 yilında gösterime giren "Ekümenopolis (Ucu Olmayan Şehir)" filminde, Ayazma ve Sulukule yıkımları halkın yaşam öyküleri ile farklı meslek gruplarının konuya yaklaşımları göz önünde tutularak film karelerine aktarılmıştır. Bu yıkımların filme konu olması bütünüyle kentsel dönüşümün nasıl algılandığının sunulmasında çarpıcı bir görsel örnek olarak kabul edilebilir. İmre Azem'in yönetmenliğinde hazırlanmış film belgesel nitelindedir. Film gökdelenler ile yoksulluğun temsilcisi eski bina ve gecekonduların bir aradalığının yer aldığı görseller ile birlikte başlar. Filmin asıl ilgi çekici noktası ise, isminin taşıdığı anlamsallığa ilişkin derinliktir. Bu anlam yüklülüğün yanı sıra hatta ötesinde, kentsel dönüşümün kentsel mi, rantsal mı olduğunu sorgulayıcı bir nitelik taşımasıdır. Filmi bütünüyle kuşatan bu sorunsal kentin betonlaşma ve soylulaştırma serüveninin sosyolojik arka planının okumasının yapılmasını gerekli kılması bakımından önem taşımaktadır. Çünkü burada unutulmaması gereken husus; kentsel dönüşümün sadece ekonomik yapıyı değil, aynı zamanda toplumsal, mekânsal ve kültürel yapıyı da derinden etkilediğinin dikkate alınarak, konunun bütüncül bir perspektifle ele alınmasının önemine ilişkindir.

"Ekümenopolis (Ucu Olmayan Şehir)" tam da bu anlamda kentin, kentleşme deneyiminin, kentsel dönüşüm olgusu etrafında şekillenen TOKİ ile ilintilendirilen ve TOKİ tarafından yapılan konutlarındaki bu tarz yaşamsallığın ayrımlaşmaya yol açması ve kentsel adaletsizliğin yeniden üretilmesi noktasında önemli bir film olarak karşımıza çımaktadır. Belgesel nitelikli 2011 yapımlı filmde; mimarlar, şehir plancıları, kent sosyologları, iş insanları ve politikaciların yanı sıra kentsel dönüşümü deneyimleyen insanların gözünden de konuya yaklaşılmıştır. Artık kurulan hayatlar sadece yerinden edilen insanlar açısından bakıldığında, yıkılan basit tuğla parçalarının öte- 
sinde yaşamsallıklarının da yok sayılması ve bir anlamda ortadan kaldırılması anlamına gelmektedir. Bu bağlamda "Ekümenopolis (Ucu Olmayan Şehir)" belgesel filmi, kentsel dönüşüm olgusunu toplumsallık ve hafiza belleğinin yitirilme süreçlerini de gözler önüne sermesi bakımından oldukça önemli bir tartışmayı açıkça gözler önüne sermektedir. Filmde adeta yoksulluk barınakları olan gecekonduları devletin yıllarca görmezden gelen tutu$\mathrm{mu}$ ve sonrasında ise gecekondularının yıkılarak yoksullarının yerinden edilme süreçleri aktarılmıştır. Ucuz işçi olarak yerinden göç ettirilen ya da etmek zorunda bırakılan insanların bambaşka hayat kurma süreçlerinin önlerine bir anlamda kilit vurulmuştur. Böylelikle bu insanlar kentin dişlarında TOKİ adıyla verilen konutlara yerleştirilerek bir anlamda sönümlenmekte ve kentin çeperlerinde yaşamsal ve aktif kamusal alandan dışlanmaktadırlar. Bu dışlayış, göç eden insanların yani yeni kentlilerin bir anlamda istenmediğine dair kent politikalarının açık bir göstergesidir. Çünkü TOKI'nin, yoksullar ve varsıllar arasında adeta risk oluşumunu tetiklemesi anlayışının derin etkisi sebebiyle bu iki sınıf arasındaki açıkça ayrımlaşmayı doğurduğu ifade edilebilir. Dolayısıyla TOKİ'lerin varlığı nedeniyle kentler, sınıfsal olarak güvenli sitelerde yaşayan üst sınıf ile korunaksız ve temel yaşam ile hizmet alma alanlarından uzaklaştııılan alt sınıf arasına bir anlamda sınırların konulması nedeniyle kutuplaşmalar yaratılarak ayrımlaştırilmaktadırlar.

Film, yoksul bir evin mekânsal olarak nasıl göründüğüne ilişkin bir kare ile başlamaktadır. İçerisinde hala bir miktar tuğlanın bulunduğu, camları olmayan pencerelerin kartonlarla kapatılmaya çalışıldığı, hurçlarla yüklük ve dolapların yerlerinin doldurulmaya çalışıldığı, 1980'lerden itibaren Türkiye özelindeki temel eğlence unsuru haline gelen ve bir kentin gelişmişlik göstergesi olarak sunulan televizyonun, o evde yaşayan bir çocuğun çizgi film izleme isteği ile başlamaktadır. Çocuğun televizyonda açtığı kanalda ekümenopolis adı animasyonlarla birlikte görülmektedir. Filmde tarihsel bir düzlemde Geç Osmanlı döneminden itibaren günümüze değin kapitalizmin geçirdiği aşamaları kent yapısındaki değişim ve dönüşümleriyle ve kentsel dönüşüm olgusuyla konutlar ile yaşam alanlarının nasıl evrim geçirdiğine ilişkin sosyolojik bir metin etrafinda irdelenmektedir.

Geç Osmanlı dönemini yarı sömürge bir ülke olarak değerlendirilen filmde, ülkenin özel sermayenin elinde olduğuna ilişkin vurgu yapılmaktadır. 1923 yılında ise cumhuriyetin kurulmasıyla birlikte sermayenin Türki- 
ye'yi terk ettiğine değinilmiştir. 1929 yılını belirtirken dünyadaki ekonomik buhrana ve bu krizin ülkeler açısından önemine değinmesi söz konusudur. Bu dönemin Türkiye'deki sanayinin devlet eliyle yapılması yani devletçilik ilkesinin etkililiğine, kamu fabrikalarının gelişmesi ile ulaşımın demiryolu ağları ile güçlendirildiği bir dönem olduğuna da dikkat çekilmiştir. Tarihsel olarak kentleşme olgusunun aktarıldığı bu belgeseldeki eleştirel perspektif, Menderes dönemine ve sonraki neo-liberal politikaların kentleri nasıl ayrımlaştırdığı ve sınıfsal açıdan nasıl olumsuz etkilediğidir. 1945 yılı itibariyle başlayan çok partili dönemde Menderes yıkımlarının gerçekleştiği, tarihi tramvayların devlet eliyle söküldüğü ve yerlerine otoyollar inşa edildiği bilgisi filmde aktarılmıştır. Bu noktada en dikkat edilmesi gereken nokta ise Toprak Reformunun yerine Marshall yardımlarının kabul edilmesiyle ve tarımda makinalaşmanın başlaması nedeniyle işsiz kalan topraksız köylülerin yoksullaşmalarına bir anlamda zorunlu olarak kentlere göç ettiklerine ilişkin sosyolojik okumaya dairdir. Gerçekleşen bu içgöçün ekonomik anlamda istihdam boyutu tartışldığında ise ucuz işgücü yani ucuz emek kavramı karşımıza çıkmaktadır.

Köylülerin kentlerde çalışabilecekleri alan ancak enformel yani marjinal sektör ya da fabrikalarda işçi olmaktan öteye gidemeyen bir alt sınıflılıkla eş değer tutulmuştur. Bu kesimi yani kente göç edenlerin konut problemi ise hiçbir şekilde çözülmemiş, sorununun özü görmezlikten gelinmiştir. Dolayısıyla göçmenlerin ya da yeni kentlilerin barınma ihtiyaçlarını gidermek için kendi başlarına gecekondu yapmaları söz konusu olmuştur. Dünya genelindeki 1973 petrol krizinin yaşandığı dönemde, Türkiye özelinde 1. Boğaziçi Köprüsünün yapılmasının ve çoğalan fabrikalar nedeniyle gecekondulaşma oranında ciddi artışlar gösterdiği İstanbul oldukça önemli 'çekim merkezi' haline gelmeye başlamıştır. Zamanla orta sınıfın banliyölere taşınması ve toplum genelinde tüketim olgusuyla tanışıldığı, adeta yaşamanın ve statü elde etmenin ancak tüketerek var olunabileceğine dair kapitalist söylem bu dönemle birlikte kendisini hissettirmeye başlamıştır. Beraberinde Latin Amerika modeliyle benzerlik olduğunun söylenildiği 24 Ocak kararlarını, Özal'ın 1980 darbesinin sonrasındaki etkisi ile uygulanmaya konulmasiyla birlikte Türkiye, neo-liberalizm denilen serbest piyasa modelinin kabul edildiği bir ekonomik modele geçmiştir. Serbest piyasa ekonomisini temel alan bu modelin uygulanması beraberinde Cumhuriyet döneminde oluşturulan Tekel, Seka, Tüpraş gibi fabrikaların da satılmasına ve burada 
çalışan işçilerin işsiz kalmalarına yol açmıştır. Bu doğrultuda mekânın giderek sömürgeleştirmeye ve metalaşmaya daha fazla alan açması, satın alınması nedeniyle kullanılması ve suiistimale uğramasına değinen Merrifiel'e değinmek yerinde olacaktır. Çünkü onun açısından bu kentin kapitalizm tarafından ele geçirildiğinin de bir anlamda göstergelerini sunmaktadır (Merrifield, 2012, s.187).

İmar aflarıyla apartmanlaşma söyleminin sahibi Özal'ın yoksullaşan işçi kesimine orta sınıflaşma formülü konut problemini ortadan kaldırmaya yönelik neo-liberal politikalar etrafında bulduğu çözüm yolu da metalaşmanın varlığına ilişkindir. Kentsel alanın gelişmişliğin göstergesi olarak 1988 yılında açılan 2. Köprünün gösterilmesidir. Belgeselde Fatih Sultan Mehmet köprüsünün yapılması ve açılması ile sosyolog akademisyen Şükrü Aslan'ın belirttiği üzere, Ümraniye ve Kâğıthane ilçelerinin hızla nüfusunun artışında olduğu gibi aslında yerleşimin doğrudan etkilenmesi bir anlamda tetiklenmesi söz konusudur. Neo-liberalizmin kentleri istila edişinin en önemli görünümü ise emlak rantlarının zamanla artış göstermesi ve bunun dünyada gittikçe artan gelir adaletsizliğin mekânsal izdüşümünden kaynaklanmasıdır. 1990'lardaki küresel kent söyleminin yaygınlığı, tüm bu adaletsizliğin özellikle azgelişmiş ülkelerde daha da derinden hissedildiğini göstermektedir. 2000'li yıllara gelindiğinde ise toplumsal ayrışma kentlerde çok daha belirginleşmeye başlamıştır.

Mekânların konumlandırılışındaki sınıfsallığın yadsınamazlığı kentsel dönüşüm adı altında insanların yerinden yurdundan edilmelerine dair olumsuz hikâyelere gebe olmaktadır. Bu belgesel tarihsel arka planını çizerek toplumsal ve politik açıklamalar etrafında özellikle 2000'li yıllardan itibaren TOKI'lere yerleştirilen insanların borçlandırılmasında, adeta 'kuş uçmaz kervan geçmez' çeperin de çeperine itildiği bir anlamda toplu mezarlıklar olarak nitelendirildiği ve kapitalizmin insani yaşamının ne kadar uzağında kaldığının Türkiye özelinde Ayazma ve Sulukule örneklerinde yakın geçmişte yaşanan kentsel dönüşüm örneğini göstermektedir. Çünkü tüm bu hikâyeler belgeselde de açıkça ifade edildiği gibi emekçi kesimin, sermaye güçleri tarafından kentin merkezini esas inşa edenler olmalarına rağmen kentin dışına itilmeleri söz konusudur. Küresel kent ve aynı zamanda finans merkezi olmanin göstergesi, emekçileri kentin periferine göndermekle eş değer tutulduğu için, sermaye ve kent ilişkisinde sınıfsallığın tartışılması gereklidir. Üzerinde dikkatle durulması gereken diğer bir önemli nokta, 
finans merkezli bu ekonomik yapılanmanın kentsel alanları önemli rant alanı olarak kabul etmesi ile birlikte global sermaye için sermayenin dolaşıma girmesi ile azgelişmiş ülkelerin kentlerini doğrudan kendisine çekmesine yani etkilemesine ilişkindir. Bu noktada Harvey, sermaye ve kentleşme arasındaki ilişkiyi "sermaye birikimi ve kentleşme süreci el ele yürür" şeklinde özetlemiştir. Sermaye dolaşımı, emek ve mal piyasalarının, üretim ve tüketimin sosyo-mekânsal bölünmesinin ve örgütlenmiş finansal sistemlerinin düzenlenmesi yoluyla kent mekânına yerleşmektedir (Harvey, 2016, s.42). Bu bağlamda kenti sadece fiziksel bir yerleşim yeri olarak algılamak büyük bir yanılgıya düşmeye yol açar. Çünkü özellikle Castells'in de aktarmasına göre kent, fiziksel bir yapıdan çok sürekli değişim içerisinde olan bir toplumsal pratiktir. Kente müdahale aşamasında planlama ile toplumsal dinamikler arasında karşılıklı etkileşim olduğu noktasının ele alınması da büyük bir önem taşımaktadır (Castells, 1997, s.31-32). Bu etkileşimin olmadığı noktada ise kentlerdeki kapitalizmin vahşi doğasının keskin etkisi nedeniyle, kenti bir anlamda yutmaya kararlı ve Yunanlı kent bilimci Constantinos Doxiadis'in de korku şehir olarak adlandırdığı üzere Ekümenopolis'in İstanbul gibi metropol kentlerle ilintili olarak değerlendirmesine ilişkindir.

Betonlaşmanın her geçen gün arttı̆̆, insani yaşam ve nefes alma alanlarına izin verilmediği ve bir anlamda saldırıldığı, gökdelenlerle insanların statülerinin arttığına dair kapitalist anlayışının her geçen gün hız kazandığı bu eşitsiz yapılanmalarda fazla nüfusun beslenemediği bir kentin gelişmişlik göstergesi adı altında sömürüldüğü ve aslında yok edilmesi söz konusudur. Gökdelenlerin varlı̆̆ı bile iktidar ilişkilerinin sınıfsallı̆̆ını açıkça ortaya koymaktadır. Bondi'nin de belirttiği gibi "binaların yüksekliği çoğu zaman mülkiyet ve arazi kullanımına yönelik ekonomik kararlar ile ilgili olsa da dikeylik, gücü temsil etmek için sık kullanılan bir kültürel seçimdir" (Bondi, 1992, s.160). Ayrıca Lefebvre benzer görüşü destekler nitelikte dikeyliğin ve yüksekliğin bir iktidarın mevcudiyetini mekânsal olarak daima ortaya koyduğundan bahsetmektedir (2000, s.122). İktidarın mekânsal ayrımlaşmasındaki metropol bir kent olan İstanbul'un kentsel dönüşüm deneyimlerini konu alan bu filmde, bu kentteki yoksulların insanca yaşamalarına izin verilmediğine ilişkin temel savunu beraberinde kaosun yaşanılmasının kaçnılmazlığına ilişkindir. Burada mekânın sosyolojik anlamına yönelik olarak bir sorgulamanın yapılması önem kazanmaktadır. 
Öyle ki mekânın konumlandırılışı buradaki hegemonik güç ilişkilerinin yapısını anlamayı da özellikle gerekli kılmaktadır. Massey'in de belirttiği üzere mekân, farklı konumlara sahip farklı kişiler tarafından farklı deneyimlendiği için mekânlar ve mekân temelli kimlikler, (places and place based identities) açık biçimde görülmeyen mekânsal farkları da kapsamaktadır (2001, ss.1-16) ki bunlar da görülmeyen iktidar ilişkilerinden oluşmaktadır. Bu noktadan bakıldığında iktidar ilişkilerinin mekânsallığın kurgulanmasında açıkça etkili olduğunu söylemek mümkün gözükmektedir.

Her toplumsal yapının kendine özgü zaman ve mekân pratikleri olduğunu, toplumsal zamanın ve toplumsal mekânın toplumsal pratiklerle farklı şekillerde kurulduğundan bahseden Harvey'de (2014, s.230) de olduğu gibi kentsel dönüşümü deneyimleyen Sulukule ve Ayazma halkının Bezirganbahçe ve Tozkoparan'a yerleştirilmesiyle başlayan (anti)sosyal yaşamsallık sosyolojik perspektifle analiz edilmelidir. Yine aynı perspektifle Certeau'da (2008, s.176) da ifade edildiği gibi mekânın günlük alışkanlık, tutum ve uygulamaların etkilenmesi ile yine hafıza belleğinin ve zamanın mekâna eklemlenişinde mekânın, zaman tarafından yok edilen bir boyuttan öte kesişimselliğinde yatması söz konusudur. Filmde de açıkça bu kesişimselliğin nasıl iç içe olduğundan bahsedilmektedir. Çünkü yerinden edinilen halkın TOKİlere taşındırılması aslında bir anlamda kentin en yaşanılmaz alanlarına itilmeleri, neo-liberal piyasacı politikaların bu kadar keskin bir şekilde sınıfsal uçurumu derinleştirici ve haliyle yıkıcı etkisinin olduğuna, hem de bir yandan da mekânların nasıl tüketildiğine ve bunun da 1970'ler sonrası petrol krizinin azgelişmiş ülkelerde çok daha fazla olumsuzlayı etkisinin kentsel boyutuna ilişkin analizinde saklıdır. Neo-liberal politikalar, Gottdiener'ın da ifade ettiği üzere "kapitalizmin mekânda yeniden üretimini sağlamak maksadıyla sosyal, ekonomik ve kültürel alanda yapılan düzenlemelerdir. Bu uygulama kent mekânında değişime neden olmuştur. Bu politikalar, sermayenin dolaşımını desteklemek için mekânı yeniden keşfetmiş ve yeniden üretmiştir"' (Gottdiener, 2001, s.253-256).

Belgesel 6 temel bölümden oluşmaktadır. Bu bölümler:

1. Bölüm: Küresel Kent

2. Bölüm: Sistemin Dinamikleri

3. Bölüm: Üçüncü Köprü

4. Bölüm: (Anti)Sosyal Konut Modeli 
5. Bölüm: Plan Sermaye ve Demokrasi İle

6. Bölüm: Mahalle'den oluşmaktadır.

Ayazma ve Sulukule'de gerçekleşen yerinden edilme öyküsü kent, kentleşme, kapitalizm, insani yaşamdan uzak yaşamlar ile bu başlıklar etrafında tarihsel, politik, sosyolojik ve eleştirel perspektifle aktarılmıştır. Kapitalizmin özellikle 2. Dünya savaşından itibaren seri üretime ve tüketime dayalı yapısı sınıflararasındaki gelir adaletsizliğinin de gittikçe artmasına yol açmıştır. Kentsel dönüşümle birlikte TOKİlere yerleştirilmede sosyolojik olgular ve mekânın tasarlanışına ilişkin analiz de böylece belirtilmiştir. Çünkü mekân, toplumsal düzlemde farklı anlamsallığa sahiptir. Altındal'ın da özellikle dikkat çektiği üzere "yer ile mekân sık sık birbirleriyle karşılaştırılan iki kavramdır. Yer fiziksel bir boyut olmaktan öteye gidemezken, mekân o yerdeki insanların sosyal ilişki ağıyla dolaşıma girmesiyle doğrudan ilintilidir. Böylelikle mekân, pür bir yer olmaktan çok orada kurulan ilişkilenmeleri de kapsayıcı bir renge bürünmektedir. Mekânın özel ve kamusal formlarda kurulan gündelik yaşam pratikleri ise, ilişki ağlarının farklı dinamik ve deneyimlerin yeniden üretilmesiyle beslenir" (Altındal, 2018, s.6). Dolayısıyla mekan uzun yıllar salt fiziksel anlamla ifade edilmiş olsa da esasında ontolojik ve toplumsal bir kategoridir (Maltaş Erol ve Görmez, 2016, s.82). Bu bağlamda mekânın; algılanılma, tasarlanma ve orada yaşayanlar tarafından karşılıklı olarak üretilmesi anlamında çok daha derin izleklerinin olması söz konusudur. Bu doğrultuda Ekümenopolis filmine konu olan kentsel dönüşüm adı altında yaşanan bir anlamda zorunlu göç ve sonrasında hayatta kalma mücadelesinin verilmesi mekân ve gündelik yaşam pratikleri arasında kurulan ilişkiselliğinin yapısına ilişkin sosyolojik tartışmayı gerekli kılar. İster istemez bu iki olgu arasında kurulan ilişkilerin doğası gereği, varlığı ve devamı karşılıklılık temel alındığı sürece kaçınılmazdır.

Kent, iktidar, mekân ve sınıfsallık temelinde aktarılanlar bağlamında hegemonik güç ilişkisinin mekânsal boyutu kentsel dönüşümde kendisini belirgin olarak göstermektedir. Burada önemle düşünülmesi gereken temel nüve şudur ki, kentsel dönüşüm kavramındaki dönüşümün iyileştirmeye yönelik bir girişimde ve evlerin yaşanılabilir hale getirilmesinde bu evlerin yıkılarak ranta açık alanlar şekline getirilip büyük sermaye sahibi müteahhitler tarafından rezidansların yapılmasıdır. Oysa kentsel dönüşüm kavramı Ataöv ve Osmay'ın da belirttiği üzere “kentsel sorunların çözümünü sağla- 
yan ve değişime uğrayan bir bölgenin ekonomik, fiziksel, sosyal ve çevresel koşullarına kalıc bir çözüm sağlamaya çalışan kapsamlı bir vizyon ve eylem" olarak tanımlanmaktadır (Ataöv ve Osmay, 2007, ss.57-82). Bu kavram kentsel mekânların iyileştirilmesine yönelik strateji ve eylemlerin tamamına ilişkin olması gerekirken, anlamından uzaklaşarak dönüşümün, kapitalist sermaye ile devletin işbirliği şeklinde yoksul ve kente göç etmiş insanların mekânsal anlamda yerinden edinmelerine yol açan değişime bürünmüştür. Betonlaşmanın bir ülkenin gelişmişlik göstergesi olarak sunularak ifade edilen kapitalist kent olabilme algısının postmodern ve gerçeklikten uzak yapısı da bu anlamda sadece eşitsiz güç ilişkilerini değil aynı zamanda nefes alınılacak yeşil alanların ve tabii ki doğanın yani tüm habitatın yok edilmesine yol açacağı için açıkça bir tehditin izleklerini sunmaktadır. Bu noktada Mimar Mücella Yapıcı'nın Amerika örneğini ifade ettiği söylemindeki 'Siz Central Park'a Bir Otel Yapabilir Misiniz?Hayır mümkün değil çünkü oradakiler bilir ki bir kentin nefes almast için gereklidir o alan' vurgusu kentlerin yutulduğunu ve sönümlendiğini, yaşamların da yok edildiğine dair oldukça önemli bir farkındalığı da ortaya koymaktadır. Bu noktada yine Harvey'e değinmek yerinde olacaktır. Çünkü Harvey (1992) kapitalist kentin neden ve nasıl üretildiğine değin vazgeçilmez sorusunu sorarak, kentsel gelişme ve sermayenin hareketi arasındaki ilişkiyi değerlendirerek sınıfsal yapı ve mekânsal farklılaşma arasındaki ilişkiselliği sorgulamıştır. Ayrımlaşmanın kapitalist sistem ile bağını kentsel alandaki sınıfsallıkla açımlaması da kentin ekonomi politiğini tartışmak açısından önem taşımaktadır. Yine bu bağlamda 3. Boğaz köprüsünün yapılmasının ulaşım sorununu çöz(e)meyeceği noktasına değinen Mimar Oktay Ekinci'nin de vurguladığı üzere aslında İstanbul'u diğer metropollerden ayırt edici bir noktası Karadeniz ile Marmara Bölgesi arasında 30 km'lik bir alana sıkışmış bir konumda yer almasıdır ki bu artan nüfusun kentte nasıl yerleşeceği konusunda ciddi sıkıntıları ortaya çıkaracaktır. Yine Mimar Mücella Yapıcı'nın bahsettiği üzere yol ve otoyolların yapımının insanları oraya çekmesi ile arasındaki doğrudan ilişki ister istemez Sultanbeyli örneğinde olduğu gibi kaçak kentlerin ortaya çıkısına da zemin hazırlayacağı öngörülmektedir. Yol yapmak sadece bir hizmetten öte aksine insanların burada yaşayabileceğine dair ipucunu da vermektedir; ancak tam da bu noktada, yapılan yeni yollar beraberinde sosyal politik alanı dikkate almayan neo-liberal politikalar nedeniyle arsa spekülasyonlarına da yol açmıştır. 
Kent hakkına ilişkin hiçbir örgütlenmenin olmamasının doğal sonucu olarak ortaya çıkan kentsel dönüşümün yıkıcı etkilerinin ve kapitalizmin insanların yaşam haklarının insanların ellerinden alınmasına ilişkin mekânsal içerimleri filmde; mimarlar, şehir plancılar ve sosyologlar tarafından özellikle dillendirilmektedir. Sosyolog Akademisyen Şükrü Aslan'ın özellikle kentin pay edilmesindeki adalet vurgusu, sosyal politik alanın yeniden dizayn edilmesine ilişkin önemli bir ikazdır. Gelirin artmasının öneminin yanında, asıl önemli olanın gelirin paylaşılması olduğu dikkate alındığında, varsıl ile yoksul arasındaki mevcut farkın gittikçe büyümesinin büyük bir sınıfsal tehlikeyi ortaya çıkarması olasıdır. Tarım arazilerinin yok edildiği, betonlaşmanın durmaksızın artarak ve her geçen gün iklim değişikliğini hissettirerek canlıların yaşam alanlarını yok ettiği, hızla artan nüfusun ekonomi tarafından beslenemediği, istihdam sorunlarının gittikçe çoğaldığı, gelir adaletsizliğin neo-liberal politikalarla gittikçe arttığı, sınıfsal uçurumun derinleştiği bugünkü mevcut toplum yapısında kent hakkının sunulduğundan bahsetmek olanaklı gözükmemektedir. Bu doğrultuda önemli olan ayrımlaşmanın mekânsal olarak gerçekleştirilmesinin önüne geçip, tüm sınıfların bir arada yaşamalarının gerçekleşmesine ilişkin sosyal adalet ilkesinin bir an önce uygulama alanına konulmasının gerekliliğine ilişkin vurgunun öneminde yatmaktadır. Filmin girişinde de kentsel nüfusun artmasıyla ilgili olarak "Kentler buna hazır mı?" derken aslında tam da nüfus ve kentin kapsamı arasındaki bu orantısızlığın günümüzdeki görünümüne ilişkin önemli bir soru sorulmaktadır.

Filmin diğer bir değeri, yerinden yurdundan kopuş hikâyelerini pür inşaat sektöründeki kişilerle sınırlandırmamış olmasından kaynaklanmaktadır. Mimarlar, şehir plancıları, politikacılar, müteahhitlerin yanı sıra sosyologların da konuya yaklaşımı kentsel dönüşümü deneyimleyen Kasım Aydın gibi iş bulmak umuduyla kente gelip, evlerinin yıkılıp, bomboş arazilerde inşa edilen TOKİlerde borçlandırılarak yaşamak zorunda bırakılan insanlar açısından da görebilmeyi ve duyarsayabilmeyi daha anlamlı hale getirmiştir. Burada yaşanılanın, yani yıkılanın sadece tuğla parçalarından öte hayatların olduğunu görmek önemlidir; çünkü yaşamların yok edilmesi aynı zamanda o evlere ait hafıza belleklerindeki izlerin de silinmesi anlamına gelmektedir. Filmde bir buzdolabının üzerinde duran “Deyimler Sözlüğü" kitabının gösterilmesi, tam da bu noktada o evde yaşayan ve eğitim hayatına devam eden çocukların olduğuna dair bilgi vermektedir. Dolayı- 
sıyla evlerin yıkılması, çocukların eğitim hayatlarının nerde devam edeceğine, edebilme olanağının olup olmadığına ve çocukların o yaşlarda evsiz kalmanın travması ile karşı karşıya kalma sorunlarını yaşamalarına, yine kadınların bu yıkılmalar karşısında en çok etkilenen bir başka grup olarak evlerinin yıkımının ardından çadırda yaşamak zorunda kaldıkları dönemde suyun olmadığı yerde nasıl hayatta kalınabilirliği sorunu karşısında çaresiz bırakılmaya yol açmaktadır. Ailelerin evlerinin yıkımının sonrasında çadırlara yerleştirilmeleri ile yaşadıkları ve daha sonra TOKI'lere borçlandırılarak geçirilmeleri kentsel dönüşüm kavramının asıl anlamının çok dışında ele alındığının açıkça göstergesidir. 20 Kasım 2008'de evleri yıkılan ailelerin kurdukları dayanışma çadırları ve İkitelli Ayazma Kentsel Dönüşüm Mağdur Aileleri oluşumu Aralık 2009'da Küçükçekmece Belediyesinden Bezirganbahçe'deki sosyal konutlara yerleştirilmeleri için yaptıkları başvurunun ardından TOKİlere geçiş süreçleri insani yaşam alanlarından ne kadar uzağında kabul edildiklerini göstermektedir. Filmde ayrıca "Yaşam Mimarı" adıyla tanınagelen Ali Ağaoğlu'nun beyaz baretiyle ne mimar olduğu ne de yaşanabilir hayatlar sunduğu, yerlerinden edilen halkın arazilerinde rezidanslar inşa ederek adeta yaşam merkezleri haline getirmeye dair "mış" gibi davrandığı ve gerçeklikten öte dünyayı göstermekte olduğuna tanık olunmaktadır. Bu anlamda Ağaoğlu'nun ve onun gibi piyasa odaklı düşünen politikacıların, yarattıkları gerçekliğin temelde gerçeklik alanını sunmadığı, yoksul olmanın suçlulukla eş tutulduğu, I. Elizabeth yasaları anlayışından öteye gidilemediği, neo-liberal piyasacı toplum yapısının eşitlik duygusunun çok uzağında seyrettiği, soylulaştırmanın mekânsal ayrımlaşmalarda kendisini açıkça gösterdiği, kentin periferisinin de periferisine itilmenin belgeselin sosyolojik okumasının yapılmasıyla mümkün olmaktadır. Burada asıl dikkat edilmesi gereken diğer bir konu, Ağaoğlu ve pek çok müteahhittin de yapmış olduğu gibi "neo-liberal politikaların kentsel dönüşüm sürecini etkilemesi ve istenmeyen değişimlere neden olmasıdır. $\mathrm{Bu}$ değişim, 1980 öncesi ve sonrası kentsel dönüşüm projeleri karşılaştırıldığında farkedilmektedir. Kentsel dönüşüm projeleri, özel sektörün aktörler arasına katılımı ve payının artırılmış olması ile sermaye odaklı projeler olarak görülmektedir" (Özbek Sönmez, 2005, s.17-18). 


\section{Tartışma ve Sonuç}

Türkiye'de 1940'lı yıllarda görülmeye başlanan gecekondu olgusu, İkinci Dünya Savaşı sonrası ABD tarafından verilen Marshall yardımları ve tarımda makineleşmeyle birlikte kırsal kesimden büyük kentlere doğru olan göç sonucunda ortaya çıkmıştır. Tahire Erman'ın belirttiği üzere gecekondular, enformel konutlar alanları anlamın içermesi sebebiyle kent yoksulunun evi olarak kabul edilmektedir. Burada yaşayan bireylerin yaşadıkları mekânlar kadar kendi aralarında kurulan ilişki yapıları da enformeldir. Bu bağlamda kent merkezinin itici gücünden kentin çeperine doğru itilen ve hatta Goffman'c kavramsallaştırmayla değinilecek olunursa etiketlenen yani 'damgalanan' yeni kentliler Harvey'nin de belirttiği gibi aynı yapısal özelliklere sahip oldukları için birlikte yaşamaya ve kümelenmeye eğilimlidirler. $\mathrm{Bu}$ eğilim Goffmann tarafindan 'toplumsal kimlik' olarak nitelendirilen hemşehrilik olgusunu ortaya çıkarır ki bu olgu Altındal'ın ifade ettiği gibi yeni kentlilerin dışlanmışlık, yalnızlık, korku ve tedirginliklere karşı oluşturduğu kentte tutunabilmenin önemli bir aracı olarak enformel ilişki ağı ve bir tür savunma mekanizması olarak tampon mekanizma görevini de üstlenen bir güce sahiptir (2010). Yine benzer görüşü savunan Gilbert'in de aktardığı üzere "kırdan kente göçenler, öncelikli olarak kenti tanıma, iş bulma gibi ekonomik güçlüklerde, daha önceden göç etmiş ortak kökene dayalı olarak hemşehrilerinin bulunduğu alanlara göç ederek aynı mekânlarda kümelenlemelere neden olmaktadır (Gilbert, 1984, s.118).

Nitekim Tozkoparan Mahalle Derneğini temsilen Ömer Kiriş'in, kentsel dönüşüm çerçevesinde devlet tarafından yeni yapılan binaların depreme karşı dayanıklılığını tüm mağdurlar adına sorgulaması, bu kümelenmenin ve farkındalığın ortak sesini göstermektedir. Yeni kentlilerin barınma ihtiyaçlarını giderme, iş bulma vb. ihtiyaçlarını daha kolay şekilde karşılamak için kullandıkları hemşehrilik olgusu, tüm bunlarla beraber gecekondu mahallelerinin yasal statüye kavuşmasını sağlamak için de geçerli bir yol haline gelmiştir. 1960'lı yıllarda Demokrat Parti zamanında gecekondular için popülist yaklaşımlar içinde bulunan hükümet, oy kaygısı nedeniyle gecekondulara alt yapı ve tapu sözü vermiştir. 1980 darbesi ile gecekondu mahallelerine olan müdahale daha da artmış ve Özal Yasaları olarak adlandırılan Islah İmar Planı Yasa Grubu çıkarılmıştır. Ayrıca 1980 sonrasındaki Özal'ın kente dair aflar sürecinde uygulamış olduğu popülist politikalar nedeniyle 
serbest piyasa ilkeleri, sınıflar arasında kutuplaşmayı derinleştirmiş ve bu durum da ister istemez mekânsal ayrımlaşmalarda kendisini açıkça göstermiştir (Işsı ve Pınarcıoğlu, 2001; Erman, 2010; Kurtuluş, 2010).

2000'li yıllara gelindiğinde gecekondu mekânlarını kentten soyutlamak için yeni yasalar getirilmiştir. Bu soyutlama, Kentsel Dönüşüm Projeleri adı altında yapılmaktadır. Günümüzde ise İmar Barışı olarak adlandırılan politikalar uygulanmaktadır. Tüm bunlarla birlikte İstanbul'un ulaşım sorununu çözmeyi öngören 3. Köprü projesi de yeni rant mekanları üretme potansiyeli olarak ele alınmakta ve İstanbul'un daha önceleri $2 / 3$ oranında olan yeşil alanını 1/3 oranına düşürerek kenti yutabilecek bir güce sahip olacağı yaklaşımı, ekümenopolis fikrini desteklemektedir.

İstanbul'un Avrupa Kültür Başkenti olmasından çok kentin mekânsal ayrımlaşmalarla bölündüğü görülmektedir. Bu bağlamda Ali Ağaoğlu gibi müteahhitlerin İstanbul'u betonlaşmayla kentleşmeyi eş değer tuttuğu anlayışı nedeniyle, yeşil alanın altına otopark yapmayı çağdaşlık, parseldeki toprağın tamamını yitirip balkona ağaç dikmeyi ekolojik mimarlık sanılan gerçeklikten uzak bir anlayışın egemen olduğunu belirten Mücella Yapıcı, gecekondu mahallelerini yıkıp rezidanslığa geçilmesini olumsuzlayıcı bir dil kullanarak açıklamaktadır. Bu bağlamda Prof. Dr. Hatice Kurtuluş'un da savunduğu üzere "Gecekondu bir bina sorunundan öte asll olarak bir sosyal sorundur" çıkarımını yapmak önem taşımaktadır.

Küreselleşmenin neo-liberal politikalarla arazinin meta olarak olimpiyat stadının yapılmasıyla değer kazanmasındaki kentin rant alanına çevrilmesine değin önemli açılaması söz konusudur. Ayazma böylelikle sadece Küçükçekmece'nin küçük bir yeri değil aslında rantsal alanda önemli bir mekânsal alana sahip olan küresel sermayenin işlemesine 2008 yılındaki yıkımın ardından 2010 yılında Ali Ağaoğlu tarafından yaşam merkezi haline getirilmek üzere rezidansların inşa edileceğine dair kapitalist söyleminin en vurucu noktası "10 bin peşin, ev senin" söyleminde saklıdır. Nasrettin Hoca'nın "parayı veren düdü̈̆̈̈ çalar" kapitalizmin egemen söylemi paranın en önemli güç olduğunun savunulması ile eş değerliliği burada da görülmektedir. Buna bağlı olarak TOKİ, Kurtuluş'un da dediği üzere sınıflar arasında ciddi anlamda risk oluşumuna sebep olmaktadır. Çünkü TOKİ belediyeler aracilı̆ıyla müteahhitlere devredilmekte ve burada insanların yaşamları üzerinde yerinden edilmelerine yol açmaktadır. Ortaya çıan ve sosyolojik olarak temeldeki sorun şüphesiz sosyal devletin çöküşünün ve 
bitişinin kentsel alandaki ayrışmalarında vahşi kapitalizmin yoksulları izole yaşamlarla etiketleyerek 'mikroplu kıyılar' adını verdiği gecekondulardan sanki ayrı ve bambaşka yaşamlar sunuyormuşçasına bir dünya yaratılmasına dair bir algı oluşturmasında yatmaktadır. Ancak bu Baudrillard'cı anlamda da hipergerçeklikten başka bir şey değildir. Öyle ki bu insanların yaşamış oldukları aslında devlet tarafından ve sermaye güçleri tarafından kentsel rantlar ön planda tutularak sürgün edilmelerinde görülmektedir. Filmin 22. dakikasında yoksul bir evin duvarındaki "Avrupa Birliğine Mağdur Hakkı Yiyerek Mi Katılacağız" yazısı tam da insanların bu yerinden ediliş öyküsünün borçlandırılarak sosyal konut adı altında TOKİlerde yaşamak zorundalığına bırakılmanın dikkat çeken açıkça bir göstergedir. Dolayısıyla günümüzde değişen TOKİ yasasıyla da birlikte müteahhitler için toplu konut yapımlarında asıl amaç rant olması nedeniyle, bu alanlar barınma ihtiyacını karşılamak için insani yaşam alanları sağlamak yerine sosyal ilişkilerin zayıflatıldığı mekânlar olmaktan öteye gidememektedir.

Sonuç olarak kent çeperine itilen yoksulların, çeperden de koparıldığı toplumsal ayrışmaların önüne geçilmezse, Yapıcı'nın da dediği üzere kaosun kaçınılmazlığı söz konusudur. Bu nedenle Türkiye'de kentsel dönüşüm sorununu sınıfsal kutuplaşmadan kurtararak, heterojenliğin kentin dinamizmini sağlayacağı noktasına yaklaşılarak, yoksulluğu önleyici istihdam alanlarının arttırılması, kentsel ve mekânsal ayrımlaşmaların önünün tıkanması, soylulaştırma projelerinin yerine bütüncül sosyal politikaların etkili olduğu kentsel bütünleşme olgusunun yaşama geçirilmesine gereksinim duyulmaktadır. Çünkü kentin heterojenliğini besleyen yapısının yıkılması, beraberinde toplumsal damgalamalara gebe olacağı noktasında önemli bir kentsel adalet sorunu olarak ortaya çımaktadır. Bu bağlamda kent çeperine itilen yoksulların, çeperden de koparılmaya çalışılması ve bu süreçte toplumsal dışlamaların gerçekleşmesi sonuç itibariyle kentsel adaletsizlik olgusunu beslemektedir. Türkiye özelinde yaşanan bir kentsel dönüşüm öyküsünün aktarımı sosyolojik okuma ile değerlendirildiğinde, bu olgunun sadece bina ve yapı sorunu olmaktan öte çok daha temelde bütüncül politikaların ve yaşamsal insani boyutların bir aradalığıyla düşünülmesini gerekli kılmaktadır. Bunun gerçekleşebilmesi adına neo-liberal piyasacı politikaların 1929 dünya ekonomik buhranından günümüzde değin kapitalizmin karşılaştığı krizlerden çıkabilmesi ve sınıflar arasında yaratmış olduğu eşitsiz uygulamaların yerine ve özellikle 1990'lardan itibaren dünya kapita- 
lizmdeki yaratılan finansallaşmanın yıkıc etkisinin yerine sosyal adalet ilkesinin uygulanmass elzemdir.

Kentsel yaşam alanlarının var olduğu, kentsel dönüşümün insanları etiketlemeden ve ötekileştirmeden yaşadığı mekânın iyileştirilerek, yaşayanların borçlandırılmadan kentin merkezlerinde yaşamlarını sürdürebilecekleri, uluslararası sermayenin azgelişmiş ülkeler üzerinde uyguladıkları neoliberal politikalardan uzak, dolayısıyla sinıf ve sosyal devlet odaklı ekonomik ve toplumsal politikaların uygulanması en önemli çözüm ve çıkış yolu olarak kabul etmek olanaklıdır. Aksi taktirde belgeselin son karesinde görüldüğü gibi halkın örgütlenerek "doğduğu mahallelerde mülteci olmayı istememek" şeklindeki dövizlerde yazıldığı gibi sokaklara çıkabileceği olasılığı dikkate alınarak gecekondulardan toplu konutlara taşınmaları taksitlere bölünmüş olsa da borçlandırılarak yerinden edilmelerinin, insanların en doğal barınma ve sosyal yaşam hakkına müdahale olarak algılanabileceği için sınıflar arasında mekânsal ve toplumsal ayrımlaşmalar yaşanacaktır. Bunu önlemek adına mevcut konutlarının iyileştirilmesi gerçekçi ve sosyal adaletin gerçekleşmesine dair çözümü sağlayacaktır. 


\section{EXTENDED ABSTRACT}

\section{On the Axis of theRepresentation of Urban Justice Sociological Reading of Ecumenopolis (City Without End)}

Yonca Altındal

Balkesir University

The phenomena of urbanization, modernization and capitalization are directly related to each other. The phenomenon of urbanization, in its general view, is a phenomenon that requires the inclusion of economic, social, cultural and political contexts, not only as the agglomeration areas of the population living together. In this sense, urbanization has broken away from homogeneity and evolved into a heterogeneous identity where differences coexist. Thus, the meanings attributed to the city have changed and transformed over time. Because of this mobility, it is not possible to talk about the existence of a single urbanization. The decisive factor in this is the position of the countries in the summer of development. Therefore, until a country is a developed, developing or third world country, it is necessary to examine the social aspects of urbanization. When we look at the levels of development of countries, it is seen that this difference is especially evident in the urbanization process in underdeveloped countries and its relationship with industrialization. Less developed countries, is affected by the hegemonic centers of capitalism and progress in the process they can perform low due to the increased level of development closing the economic gap between the developed countries, with increasingly a little further each year as a result of growth they are falling behind.

When we look at Turkey's urbanization adventure, it is possible to say that it happened more quickly and unplanned compared to developed and capitalized countries. Since the 1940s, the Inner Wave calls for migration to the big cities, but in a sense it is due to the existence of mandatory economic conditions. The failure of the agrarian reform to be implemented with the Democratic Party period, however, led to the transition to mechanization in agriculture with the help of Marshall, and the migration of peasant people 
who were unable to work their land to the cities and then became cheap laborers. At the same time, many social policy areas such as the right to shelter, the right to life, the right to education, and the right to health have been questioned. In a sense, migration and its aftermath have been ignored.

With the migration, it was tried to find a solution to the housing problem of the people not by the state, but by making slums with the Domestic Relations of the emigrants. Over time, the numbers of poverty have increased, both from the point of view of the slums and the people living here. Because of economic and social changes, poverty does not only occur with scarcity of income. In particular, the collapsing economies of underdeveloped countries, as a result of this, there are gaps in the class structure that are being reshaped in the social structure that is being differentiated. Due to the nonimplementation of social policies, the poor in the cities were forced to live under more difficult conditions with the disappearance of the protection of urban social services and the social state. Slums have been considered important voting potential places at election times in Turkey. Accordingly, it has been tried to give legal status to the structures that are considered illegal by giving the slums "zoning" or "land grant amnesty" title deeds. In this way, slums are shaped around populist policies. In the 1960s, the government was involved in populist approaches to slums in its time by the Democratic Party, and due to vote anxiety, the slums were promised infrastructure and Land Registry. With the 1980 coup, the intervention in slum neighborhoods increased further and the reform Development Plan Law Group called Özal laws was enacted. Furthermore, due to the populist policies that Özal implemented in the amnesty process of the city after 1980, the free market principles deepened the polarization among the classes and this situation showed itself clearly in spatial separations.

Under the name of urban transformation, which is very much on the agenda today, the places and houses where many lower class and poor people live were demolished and people were displaced and placed in Toki. There is a situation where there are problems of transportation for people whose homes have been destroyed and who are forced to live in the periphery of the city by borrowing, and where education and health centers do not even take place when they are moved to housing. Spatial segregation also leads to social segregation over time, fueling possible conflicts between classes. This decomposition, in which the upper class does not want to ac- 
cept the lower class spatially, over time pushes the lower class towards its non-acceptance to the upper class. The heterogeneous structure of the city pushes towards polarization along with this separation and gentrification, and the lands of displaced people become open spaces to rant. In this sense, serious difficulties arise in the representation of social justice.

The documentary Ecumenopolis (City Without End) also presents a cross-section of the Istanbul story of urban transformation. The class context brings with it the spatial discrimination in the residential areas of cities, and thus the unequal distribution is clearly felt. In the documentary, those who experience this displacement are evaluated around many different perspectives, such as politicians, architects, sociologists. The documentary also discusses the fact that Istanbul can no longer carry the population as a settlement, that city plans are not made on the axis of social justice, and how income among classes is divided as a projection of spatial displacement, capitalism and class in sociological perspective.

\section{Kaynakça / References}

Altındal, Y. (2010). Kentleşme sürecinde hemşehrilik olgusu ve mekânsal kümelenmede yeniden üretilen kimlik. Kent ve Toplum Dergisi, 2(1). 72-85.

Altındal, Y. (2017). Kir'in muhatabı: Kadın kat görevlilerin hayat tutunma dinamikleri. Çalışma Hayatında Kadın içinde (s.231-256) .Marmara Üniversitesi Yayınları,

Altındal, Y. (2018). Mış Gibi politikalarla kamusalda görünmezliği 'korunan' sessiz yığınlar: Kadınlar, Toplumsal Cinsiyet ve Kent-Mekan Sempozyum Bildiriler Kitabl, Tarih, Yer. 6-26.

Ataöv, A. ve Osmay, S. (2007). Türkiye'de kentsel dönüşüme yöntemsel bir yaklaşım. METU JFA, 24(2), 57-82.

Brenner, N. 2000. The urban question as a scale question: Reflection on Henri Lefebvre, urban theory and the politics of scale. International Journal of Urban and Regional Research, 24(2), 361-378.

Bondi, L. (1992). Gender symbols and urban landscapes. Progress in Human Geography. 16(2). 157-170.

Castells, M. (1997). Kent, sınıf, iktidar. (Çev. A. Erendil), 1.Baskı, Ankara:Bilim ve Sanat Yayınevi,.

Certeau, M. (2008). Gündelik hayatın keşfi ı. eylem, Uygulama, Üretim Sanatları. Ankara: Dost Kitabevi Yay. (Orijinal yay. yılı 1990) 
Clarke, Simon, (2005). The neoliberal theory of society. (A. Saad-Filho and D. Johnston Eds.), Neoliberalism A Critical Reader içinde (s.50-59), Pluto Press, London,

Davis, M. (2007), Gecekondu gezegeni. İstanbul: Metis Yayınları.

Ecevit, Y., (1998). Türkiye'de kadın emeğinin toplumsal cinsiyet temelinde analizi. (A. B. Mirzalıŏlu Ed.). 75 Yılda Kadınlar ve Erkekler. İçinde (s. 267-284), İstanbul, Tarih Vakfı Yayınları.

Erder, S. (2001), Ümraniye:İstanbul'da bir kent kondu. İstanbul: İstanbul Bilgi Üniversitesi Yayınları.

Erman, T. (2010) Kent ve gecekondu. Türkiye'de kent sosyolojisi çalışmaları, içinde (s. 227-265), İstanbul: Örgün Yayınevi,

Gilbert, A. (1984) Cities, poverty and development: Urbanization in the third world. New York: Oxford Universtiy Press.

Gottdiener, M. (1984). Mekan kuramı üzerine tartışma: Kentsel Praksise doğru, (Der. M.P. Smith) (Çev. Ç. Kesinok.).

Harvey, D. (1992). Class Structure and the theory of residental differentitation. The Urban Experience, (2nd Ed.), Blackwell, UK.

Harvey, D. (2014). Postmodernliğin durumu, (Çev. S. Savran). 7. Baskı. İstanbul: Metis Yay. (Orijinal Yay. yıl1 1990)

Harvey, D. (2016). Sosyal adalet ve şehir. (Çev. M. Moralı.) 5. Baskı. İstanbul: Metis Yay.

Hulme, D., Moore, K. ve Shepherd, A. (2003). Chronic poverty: Meanings and analytical frameworks. Chronic Poverty in India. (içinde) (A. Kapur Mehta ed.), Indian Institute of Public Administration (IIPA), New Delhi.

Işık, O. ve Pınarcıŏ̆lu, M. (2001), Nöbetleşe yoksulluk: Sultanbeyli örneğii. İstanbul: İletişim Yayınları.

Keleş, R. (1993), Kent ve siyaset üzerine yazılar (1975-1992) (İstanbul: IULAEMME Uluslararası Yerel Yönetimler Birliği Doğu Akdeniz ve Ortadoğu Bölge Teşkilatı Yayını, Kent Basımevi).

Keleş, R. (2008). Kentleşme Politikası, İmge Kitabevi, Ankara, 10. Baskı

Kıray, M. B. (2000). Ereğli: Ağır sanayiden önce bir sahil kasabası. İstanbul, Bağlam Yayınları.

Kurtuluş, H. (2010) Kent sosyolojisinde değişen kavrayışlar ve Türkiye'nin kentleşme deneyimi. Türkiye'de Kent Sosyolojisi Çalışmaları içinde (s. 175-225.),- İstanbul: Örgün Yayınevi.

Lefebvre, H. (2001). Mekanın üretimi. (Çev. I. Ergüden), İstanbul:Sel Yayıncılık 
Lloyd, D. J. (1979) Broad Street: Its houses and residents through eight centuries. Ludlow Research Papers, 3.

Maltaş Erol, A. ve Görmez, K. (2016). Ütopyalarda mekân tahayyülleri: Utopia'nın mekânı. Kmü Sosyal ve Ekonomik Araştırmalar Dergisi, 18(30), 81-86, ISSN: 2147-7833.

Marshall, G. (2003). Sosyoloji sözlüğ̈̈. İstanbul: Bilim ve Sanat Yayınları.

Massey, D. (2000). Space, place and gender. (3. bask1.) Minneapolis. US. University of Minnesota Press. (1. Bask1 yılı 1994).

Merrifield, A. (2012) Metromarksizm, şehrin marksist bir hikayesi, (Çev. N. Ünver), Ankara:Phoenix Yayınları,

Moulaert, F., Rodriguez, A. ve Swyngedouw, E. (Eds) (2001) Social polarization in metropolitan areas. The Role of New Urban Policy, Special Issue, European Urban And Regional Studies, 8(2), 99-102.

Özbek, S. (2005) Kentsel dönüşüm süreçlerinde aktörler-beklentiler riskler. Ege Mimarlık Dergisi, 53, 16-21.

Uyanıker Kırbaşi F. (2017) Neoliberalizmin kent üzerindeki sosyo-mekânsal etkisi: Ankara örneği. Yayınlanmamış Yüksek Lisans Tezi, Ankara Üniversitesi Sosyal Bilimler Enstitüsü Siyaset Bilimi ve Kamu Yönetimi Kent ve Çevre Bilimleri) Anabilim Dalı, Ankara.

Şenyapılı, T. (1998) Cumhuriyet'in 75. y1lı gecekondunun 50. Yılı. 75 yılda Değişen Kent ve Mimarlık, İstanbul:Tarih Vakfı,

Tekeli, İ. (2007). Türkiye'de mimarlığın gelişiminin toplumsal bağlamı. Modern Türk Mimarlı̆̆ı içinde (s. 13-36), Ankara:TMMOB Mimarlar Odası Yay

Warner, M., ve Gerbasi, J. 82004). Rescaling and reforming the state under NAFTA: Implications for subnational authority. International Journal of Urban and regional Research, 28(4), 858-873.

\section{Kaynakça Bilgisi / Citation Information}

Altındal, Y. (2020). Kentsel adaletin temsil edil(e)memesi ekseninde Ekümenopolis (Ucu Olmayan Şehir) filminin sosyolojik okuması. OPUS-Uluslararası Toplum Araştırmaları Dergisi, 15(23), 2200-2230. DOI: 10.26466/opus.688339 